as short as two millionths of a second. Messrs. Reyrolle's plant is one of the largest and best equipped short-circuit testing stations in the world. A scheme has now been initiated whereby full facilities are provided for utilising this testing plant for the benefit of the electrical industry. A company has been formed which will operate independently and will be in a position to issue national test certificates.

\section{A Piano with no Wires}

According to a recent report by Science Service, pianos are now being constructed in Kalamazoo, Michigan, U.S.A., with no strings or wires. To produce the tones, strips of steel not more than a fow inches long are made to vibrate electrically. The new instrument, called a clavier, uses a piano keyboard to operate the strips producing the notes, which are practically pure tones. These tones, which are almost inaudible, are picked up by magnetic induction and passed through an audio-frequency amplifier. The capacity of the amplifier is about ten times that of the average radio amplifier having a capacity of 30 watts. The player therefore has at his command a tone ranging from a mere whisper to one that would balance an orchestra. The impact noise sometimes audible in a piano is filtered out, and thus the pure tone is produced. The piano was invented by Prof. Lloyd Loar after experiments extending over several years. Through the use of earphones, the piano student can practise his lessons without disturbing anyone, the sound being heard only by himself. The tone volume can be varied over a wide range simply by turning a dial. The operating devices occupy very little space, the clavier consisting of little more than keyboards.

\section{Ipswich Museum}

AN appeal on behalf of the Ipswich Museum has been issued by Mr. J. Reid Moir, its president. The Museum is not well provided with exhibits illustrating the culture of the bronze age; but it now has the opportunity of acquiring an exceptional collection of bronze implements, many of which were found in Suffolk, at a cost of $£ 100$. The collection is at present on view in the Museum. Mr. Reid Moir, in issuing his appeal, does not confine himself to this immediate object; he takes a long view of the situation. Availing himself of the occasion, he suggests the institution of a body of "Friends of the Museum" who might collaborate in its work in various ways, and might, by subscription, provide a fund for use in emergencies which the provision from municipal funds could not meet for various reasons. The case for the local museum as a centre of regional scientific and historical studies is ably stated in the appeal and needs no further elaboration here. On the question of general principle, however, it may be pointed out that any proposal such as that made by Mr. Reid Moir, which helps to broaden interest among the local public in the function of its museum, deserves every encouragement. Without desiring to relieve the municipality, as the local education authority, from any responsibility that may be imposed upon it for the maintenance of the general intellectual level of its area, it must be admitted that occasions frequently arise in connexion with the work of a museum in which voluntary effort, financial or other, is salutary and expedient, or even necessary, to supplement the official obligation of the municipality.

\section{Grassland and Grazing Research}

Two new bulletins in the Herbage Publication Series have been issued by the Imperial Bureau of Plant Genetics at Aberystwyth. The first, entitled "Grazing"(Bull. No.10. 1s.6d.), consists of a collection of papers read at the British Association meeting at Leicester in 1933, each of which approaches the subject from a different aspect. The grazier's problems are put forward from a practical man's point of view, while the effect of the stock on the sward is considered in the light of experimental evidence. The Bureau has for some months been collecting information regarding the technique employed in pasture and grassland research in Great Britain and certain dominions, and the other bulletin ("Technique employed in Grassland Research in New Zealand", Bull. No. 11. 3s.) is the first publication on the subject. Questions of strain testing and building in grasses, clovers or lucerne, the breeding methods employed and the necessary corollary-the certification of herbage seeds-form the subject of several of the papers. The measurement of pasture production is considered in detail. A modification of the technique formerly described as 'alternate mowing and grazing' is put forward, while the layout of the experiments, the stage at which cuttings should be made, and the technique of stock grazing trials are among other major points dealt with. Reference is also made to two laboratory tests which have proved useful in conjunction with field work. In the first place the prussic acid content has proved valuable as a means of distinguishing between different types of wild white clover, while screened ultraviolet light has been successfully employed in ryo grass type determination.

\section{Russian Studies of Crop Plants}

THE material collected by Dr. Klinkowski on the ecological distribution of lucerne types has been translated and published in an abridged form as Bulletin No. 12 in the Herbage Publication Series of the Imperial Bureau of Plant Genetics ("Lucerne: Its Ecological Position and Distribution in the World". Aberystwyth : I.B.P.G., Agricultural Buildings. 3s. 6d.). Lucerne is the oldest forage plant known and originated from a number of regions of a 'steppe' character. The routes along which the plant migrated are traced, and the history of its development and the importance of the crop at the present time described for $\mathbf{4 5}$ different countries. The geographical distribution of the types of cultivated lucerne in Europe, Asia and North Africa is also dealt with. A further publication, "Plant Breeding in the Soviet Union", has been 
issued jointly by the Cambridge and Aberystwyth Sections of the Imperial Bureau of Plant Genetics $(3 s, 6 d$.$) .$

\section{White Pelicans of Western America}

WhERE formerly there were more than seventy nesting colonies of white pelicans in western Canada and the United States, there are now but seven large colonies. Of these, five are in Governmentprotected areas, a fortunate circumstance, since although there still exist $20,000-25,000$ of these birds in the United States, their continued existence is not so secure as the numbers might suggest. The danger which most threatens the species, according to Ben H. Thompson (Science Service, Washington, D.C.), is the draining of lakes where the nesting islands exist, but there has also to be taken into account the retaliation upon nests and eggs by fishermen who object to the pelicans' destruction of fishes, notwithstanding that in most places the birds have been found to feed mainly upon fishes not good for sport or food. A third line af control was practised for some time in Yellowstone Lake, on account of the part taken by pelicans as carriers of a trout parasite, but that policy has been given up, and the Yellowstone Park birds are now fully protected.

\section{Museums Association}

THE report of the Council for 1932-33 makes very satisfactory reading. The membership rose to 801 , and is now really representative of museum interests throughout Great Britain. Income for the year, at $£ 2,785$, was a record, the subscriptions of members exceeding by $£ 268$ those of the preceding year, and the net credit balance for the year was $£ 496$. The work of the Association has followed the lines of recent years. Co-operation with the Carnegie United Kingdom Trustees in the allocation of museum grants has been continued, and now all applications for grants must be made in the first place to the Association. A successful training course for museum curators was held at Manchester, the annual conference of 1932 at Birmingham, and there is the great venture of an Empire survey of museums, which began in 1931 (Museums $J ., 33,206 ; 1933$ ). The same number of the Journal contains an account of the very successful conference of 1933 at Norwich.

\section{Solar Physics Observatory, Cambridge}

THE annual report of the Director of the Solar Physics Observatory at Cambridge shows that a satisfactory state of progress obtains at that institution (University of Cambridge: Solar Physics Observatory. Twenty-first Annual Report of the Director of the Solar Physics Observatory to the Solar Physics Committee, 1932 August 1-1933 July 31. Pp. 3). The 3-ft. reflector is at last being put to regular use, and as a spectrograph will be obtained for it in the near future, we may look forward to a notable addition to the somewhat slender amount of stellar spectroscopy carried out in Great Britain. The Solar Physics Observatory has recently acquired additional solar apparatus in the form of a fine train of prisms by Hilger. There is now a good collection of spectrographs at the Observatory. As in past years, a number of physicists from the Cavendish Laboratory have gone out on the Madingley Road and worked at the Observatory.

\section{Bibliography of Cossar Ewart's Works}

Prof. J. H. Ashworth and Dr. F. Fraser Darling have prepared a "Bibliography of the Works of James Cossar Ewart", who died on December 31 last (Supplement to "Animal Breeding Abstracts, vol. 1. Edinburgh : Oliver and Boyd. Separate, 6d. net). The list, which contains no less than 141 titles of papers and books by Cossar Ewart alone or in collaboration with others, is a story of a long and active life of scientific investigation covering a wide range of work, from minute anatomy to animal breeding. The last reference is to a letter on "The Coat of Sheep" in Nature of March 19, 1927; it is also of interest to note that nine of Cossar Ewart's papers to the Royal Society of Edinburgh are represented by title only, so that the abstracts published in NATURE are the only records of their subject matter.

\section{Academic Assistance Council}

REFERENCE has been made in our columns from time to time to the work of the Academic Assistance Council, one of the functions of which is to assist men of science and letters who have been displaced during the political changes in Germany of the past year or so. We understand that the Council has now compiled a list of such displaced scholars, with information as to whether they have succeeded in obtaining temporary or permanent posts. The list is to be revised from time to time and sent to academic committees and appropriate institutions. The Council, the address of which is c/o Royal Society, Burlington House, London, W.1, is prepared to give further information about the movements of those on its lists in reply to responsible inquiries.

\section{The Pasteur Institute of Southern India, Coonoor}

THE annual report of the Director, Major K. R. K. Iyengar, of this anti-rabic Institute for the year 1932 has recently been issued. Patients treated at the Institute numbered 566, with 4 deaths, a mortality rate of 0.7 per cent. In addition, the anti-rabic vaccine is now issued to 107 centres in the Madras Presidency and elsewhere, and at these 8,452 persons are reported to have received a complete course of treatment, among whom were 34 deaths, a mortality rate of 0.4 per cent. Semple's carbolised sheep vaccine was used throughout the year, and 144,900 doses of this vaccine were issued; in addition to the human patients, 194 animals were also treated. No record of research work appears in this report.

\section{The Apennine Tunnel}

ON April 22 the King of Italy opened the new railway line joining Bologna and Florence. Known as the "Direttissima", this line is 21 miles shorter than the old line known as the "Porretana". The 